Arto Ikonen, Juho Jussila, Anna Laakkonen, Anna-Kaarina Linna ja Sirpa Suonpää

\title{
JULKAISUMAKSUJEN JÄLJILLÄ: KOKEMUKSIA APC-MAKSUJEN SEURANNASTA
}

Avoimen julkaisemisen yleistyessä APC-maksujen hallinnointi ja seuranta on noussut yhä tärkeämpään rooliin suomalaisissa tutkimusorganisaatioissa. Samalla on huomattu myös ne haasteet, joita maksuliikenteen seuraamiseen liittyy. FinELib-kirjastokonsortio käynnisti keväällä projektin, jossa kuusi organisaatiota etsi toimivia käytäntöjä julkaisumaksujen parempaan seurantaan. Tässä artikkelissa esitetään projektin keskeiset tulokset.

A rtikkelikohtaiset julkaisumaksut (APC, article processing/ publishing charge) muodostavat leijonanosan avoimen julkaisemisen kustannuksista ja siksi viime vuosina näitä maksuja on alettu seurata useissa suomalaisissa tutkimusorganisaatioissa. Keväällä 20I9 FinELib-kirjastokonsortion koordinoimaan APC-projektin pilottiin osallistui kuusi organisaatiota jakamaan kokemuksiaan ja pohtimaan toimivia käytänteitä julkaisumaksujen seurannan kehittämiseksi.

\section{Suosituksia hyviksi käytännöiksi}

Suomen yliopistokirjastojen neuvosto asetti syksyllä 2017 työryhmän, jonka tehtävänä oli selvittää yliopistokirjastojen nykyiset kirjoittajamaksujen hallinnan, seurannan ja tiedotuksen käytännöt sekä laatia selvityksen pohjalta suositukset hyviksi käytännöiksi. Työryhmän tuloksista julkaistu raportti on luettavissa Suomen yliopistokirjastojen neuvoston blogissa: http:// yliopistokirjastot.fi/avoimen-julkaisemisen-kirjoittajamaksukaytannot-suomen-yliopistoissa/.
Raportin laatimisen aikaan keväällä 2018 keskitettyä budjettia ei vielä ollut muilla kuin Aalto-yliopistolla, jossa rahastoa pilotoitiin. Muissa yliopistoissa projektit, tutkimusryhmät, laitokset, tiedekunnat tai tutkijat itse maksoivat APC-maksut. Lisäksi useissa yliopistoissa kirjastot maksoivat APC-maksualennuksiin oikeuttavia tieteellisten seurojen tai kustantajien jäsenmaksuja hankintabudjetistaan tai erillisestä projektirahasta.

Työryhmän suosituksissa korostuivat $\mathrm{mm}$. keskitettyjen rahastojen tarve, seurannan tärkeys ja hankintaa tekevien asiantuntijoiden lisäkoulutus avoimeen julkaisemiseen ja lisensointiin liittyen. Lisäksi työryhmä ehdotti kustantajien kanssa käytäviin neuvotteluihin yhdeksi tavoitteeksi sitä, että kustantaja ilmoittaisi selkeästi mahdollisuudesta kirjoittajamaksujen alennuksiin suoraan tutkijalle samalla kun osapuolet solmivat julkaisusopimuksen.

Työryhmän suositukset ovat edelleen ajankohtaisia ja ne nousivat esiin myös APC-projektin pilotissa. Keväällä 2019 FinELib-konsortion tietoasi- 
antuntijan Timo Vilénin luotsaamaan pilottiin lähti mukaan neljä yliopistoa (Hanken, Itä-Suomen yliopisto, Jyväskylän yliopisto, Turun yliopisto), yksi ammattikorkeakoulu (Laurea) ja yksi tutkimuslaitos (Luonnonvarakeskus) kehittämään yhdessä julkaisumaksuseurantaa. Pilotin yhtenä tavoitteena oli myös viedä suomalaisten organisaatioiden julkaisumaksutietoja OpenAPC-tietokantaan (https:// treemaps.intact-project.org/), mihin kerätään tietoa korkeakoulujen ja tutkimuslaitosten julkaisumaksuista kansainvälisellä tasolla.

Seuraavaksi esitellään pilottiorganisaatioiden julkaisumaksuseurannan käytäntöjä ja pilotille asetettuja tavoitteita.

Julkaisumaksujen seuranta Turun yliopistossa

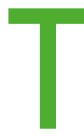

urun yliopistossa APC-maksujen systemaattista seurantaa alettiin suunnitella keväällä 2015 . Kimmokkeena oli Suomen yliopistokirjastojen neuvoston ja opetus- ja

APC-pilottiin osallistuneiden organisaatioiden edustajat.

Vasen rivi alhaalta ylös: Arto Ikonen (JYU), lina Peltonen (FinELib), Irene Ylönen (JYU), Qingbo Xu (Hanken) Keskellä:

Juho Jussila (UEF), Erik Lindgren (UTU), Timo Vilén (FinELib, projektin koordinaattori), Ari Alkio (FinELib)

Oikea rivi:

Sirpa Suonpää (Luke), Anna-Kaarina Linna (UTU), Anna Laakkonen (Laurea), Maija Merimaa (Laurea). Kuva: Marko Oja. kulttuuriministeriön edustajien tapaaminen, jossa yksi keskustelunaihe oli kirjoittajamaksujen seurannan merkitys. Turussa kirjasto ja talouspalvelut alkoivat välittömästi selvittää asiaa yhteistyönä, minkä lopputuloksena maksuseuranta käynnistyi vuoden 2017 alussa. Samaan aikaan kiinnostus kirjoittajamaksuihin kasvoi myös kansallisella tasolla.

\section{Kaksiportainen malli}

Turun yliopiston talouspalveluissa laskunkäsittelijät haarukoivat kaikesta yliopistolle saapuvasta laskuaineistosta APC-maksut ja kohdentavat ne oikealle kirjanpidon pääkirjatilille. Kirjaston

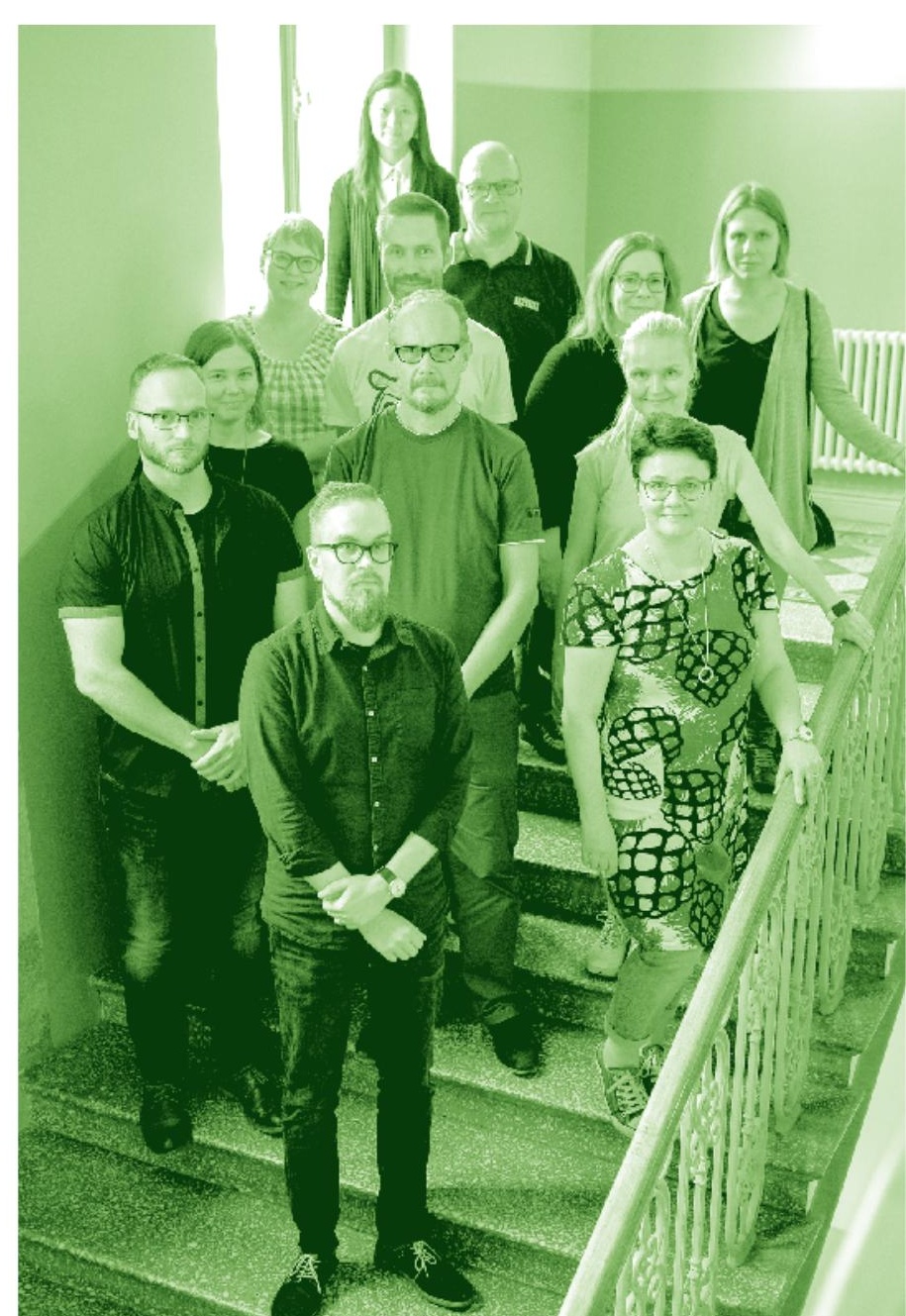


asiantuntijat tarjoavat tulkinta-apua, mikäli laskut ovat sisällöllisesti epäselviä, toisin sanoen on tarpeen tehdä rajanvetoa, onko kyse APC-maksusta vai jostakin muusta. Kirjasto on tarjonnut myös koulutusta kirjoittajamaksujen tunnistamisesta laskujen käsittelijöille.

Pääkirjatilin hallinnoinnin ja kirjoittajamaksujen tunnistamisen ohella talouspalvelut toimittaa kirjastolle kolme kertaa vuodessa koosteen (Excel), jossa näkyvät pääkirjatilille kirjatut laskut, tositenumero ja laskun maksaneen yksikön kustannuspaikka.

Tositenumeron perusteella kirjaston asiantuntija hakee laskun tiedot yliopiston ostolaskujärjestelmästä, identifioi julkaisun, julkaisukanavan ja rikastaa sen muilla tarvittavilla tiedoilla (mm. julkaisukanavan avoimuus). Kirjaston käyttöoikeus ostolaskujärjestelmässä on rajattu tositteiden hakuun ja katselemiseen.

\section{Yhteys}

\section{julkaisutiedonkeruuseen}

Laskutettavana olevan julkaisun tietojen identifioimisen yhteydessä kirjasto tarkistaa, löytyvätkö julkaisun tiedot yliopiston UTUCRIS-tutkimustietojärjestelmästä. Jos tiedot löytyvät, mutta julkaisun kokotekstiä ei ole rinnakkaistallennettu, kirjasto tallentaa kokotekstin kustantajan ehtojen mukaisesti. Jos julkaisua ei vielä ole tallennettu, kirjasto tallentaa sen sekä rinnakkaistallenteen tutkimustietojärjestelmään.

Syksyllä 2019 alkaneen APC-pilotoinnin alkaessa Turun yliopiston kirjoittajamaksujen keruuta oli tehty noin kahden vuoden ajan ja toiminta oli jo jokseenkin vakiintunutta. Pilotin alkuvaiheessa oli siten luontevaa, että jaoimme tietoa käytännöistämme ja kokemuksistamme. Pilotin edetessä löysimme silti kehitettävää myös omissa toimintatavoissamme, erityisesti julkaisutietojen rikastamiseen liittyen. Yksilöiviin tietoihin emme aikaisemmin olleet lisänneet DOI-numeroa, ja koska pilotin yhtenä tavoitteena ollut osallistujaorganisaation maksutietojen vienti kansainväliseen OpenAPC-palveluun sitä vaati, päätettiin myös Turussa tämä tieto lisätä maksutietojen yhteyteen. Tieto lisättiin myös takautuvasti vuosien 20I7-20 8 osalta.

Pilotin edetessä näkemys maksutietojen viemisen tärkeydestä vIRTA-julkaisutietopalveluun vahvistui, minkä takia myös Turun yliopiston kirjasto päätti luoda tutkimustietojärjestelmään julkaisutietolomakkeille omat kentät kirjoittajamaksulle ja maksuvuodelle. Maksutietojen siirto viRTAan päästään toteuttamaan näillä näkymin vuoden 2020 aikana.

Maksutietojen kerääminen yliopiston kirjanpidon kautta on erittäin tärkeää. Kaikki kirjoittajamaksut eivät kuitenkaan kulje yliopiston kirjanpidon kautta, mikä on käynyt entistä selvemmin ilmi osana viime kuukausina tehtyä kirjoittajamaksulähteiden kartoittamista myös organisaation ulkopuolisista tiedonlähteistä. Tarkempaa tietoa siitä, kuinka suuri osa maksuista jää yliopiston kirjanpidon ulkopuolelle saadaan kevään 2020 kuluessa. 
Julkaisumaksujen seuranta Jyväskylän yliopistossa

yväskylän yliopistossa Avoimen tiedon keskus (Open Science Centre, osc) ja yliopiston talouspalvelut alkoivat yhdessä seurata julkaisemiseen liittyviä maksuja vuonna 2018. Tarvetta seurannalle oli, sillä julkaisumaksut olivat lisääntyneet avoimen julkaisemisen yleistymisen myötä eikä kokonaiskuvaa julkaisemisen kustannuksista ollut tiedossa. Jyväskylässä pystyttiin ottaa mallia seurantaan pitkälti Turusta, sillä kummankin yliopiston taloushallinnossa ja julkaisutietojen kirjaamisessa oli jo valmiiksi yhtäläisyyksiä.

\section{Laskujen tunnistamista ja tarkistamista}

Yliopiston talouspalveluiden laskujen käsittelijät opetettiin tunnistamaan sellaiset laskut, joissa näkyy muun muassa tieteellisten kustantajien nimiä ja mainintoja, kuten publishing fee, article processing charge tai open access fee. Näiden maksujen lisäksi haaviin on tarttunut myös perinteiseen julkaisemiseen liittyviä maksuja, kuten värisivumaksuja.

Kun talouspalvelut on lähettänyt koosteen kerätyistä julkaisumaksuista, osc tarkistaa laskut ja kirjaa niistä ylös oleelliset tiedot seurantaa varten. Tämän jälkeen maksutiedot viedään yliopiston julkaisutietojärjestelmään, kuten Turussakin. Näin artikkelikohtaiset avoimen julkaisemisen maksut saadaan osaksi yliopiston keskitettyä julkaisutiedonkeruuta, jota niin ikään osc:n asiantuntijat hoitavat. Jyväsky- län yliopiston maksamat APC-maksut löytyvät vuosien 2018 ja 2019 osalta Openapc-tietokannasta ja tiedot tullaan siirtämään myös viRTA-julkaisutietopalveluun.

Keskeisin haaste maksujen seurannassa on ollut julkaisemiseen liittyvien laskujen tunnistaminen kaikesta muusta laskumassasta. Joskus julkaisumaksuja on maksettu esimerkiksi matkakuluihin varatuilla luottokorteilla. Joissain luottokorteilla maksetuissa laskuissa on voinut olla vain laskuttajan nimi, mutta ei tarkempaa tietoa siitä, mitä kyseisellä summalla on maksettu. Näissä tapauksissa julkaisemiseen liittyvät maksut ovat voineet hukkua muiden kustannusten joukkoon.

\section{Yhteistyötä eri tahojen kesken}

Keväällä 2019 alkanut APC-projektin pilotti osui hyvään saumaan, sillä osc:llä oli julkaisumaksuseurannasta jo vuoden ajalta kokemuksia, mutta samalla kaivattiin lisää tietoa muiden organisaatioiden käytänteistä. Turusta saatiin useita vinkkejä, mutta projektin aikana myös muiden organisaatioiden kanssa jaetut kokemukset ja yhdessä pähkäily auttoivat hiomaan maksuseurantaa.

Yhteistyö yliopiston talouspalveluiden kanssa jatkuu edelleen ja pilotin aikana talouspalveluissa perustettiinkin uusi tili julkaisumaksuja varten. Julkaisemiseen käytettyjen rahamäärien selvittämisen lisäksi on ollut oleellista huomata, miten tieteellinen julkaisutoiminta näkyy yliopiston rahaliikenteessä ja kuinka monta eri tahoa siihen kytkeytyy.

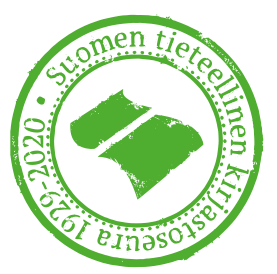


Julkaisumaksujen seuranta Itä-Suomen yliopistossa

tä-Suomen yliopiston kirjasto lähti mukaan pilottiin taskussaan vuoden 2019 alussa aloitettu kirjoittajamaksuseuranta. Seurantaan ryhdyttiin paitsi avoimen julkaisemisen hintalapun arvioimiseksi, myös yliopiston niin sanotun keskitetyn tuen kustannusten selvittämiseksi. Yliopisto aloitti vuoden 2019 alusta kirjoittajamaksujen keskitetyn tukemisen niissä tapauksissa, joissa tutkimushankkeen rahoittaja ei hyväksy kirjoittajamaksuja osaksi hankkeen rahoitusta ja artikkeli julkaistaan Jufo-luokan 2 tai 3 open access -lehdessä (gold OA). Lisäksi osa tiedekunnista hyväksyy keskitettyyn tukeen oikeutetuksi myös Jufo-luokan I julkaisut.

Käytännön seurannassa yliopiston talouspalvelut reitittävät saapuneet kirjoittajamaksulaskut kirjastoon ostolaskujen käsittelyjärjestelmässä. Kirjastossa tarkistetaan, onko kyseessä todella kirjoittajamaksu vai muu julkaisemiseen liittyvä kulu sekä kerätään maksusta tarvittavat tiedot seurantataulukkoon.

Artikkeleista ja niiden maksuista kerätään artikkelin tunnistetietoja (esim. DoI-tunnus), keskitetyn tuen seurantaan liittyviä tietoja (mm. vastuukirjoittajan tiedekunta ja julkaisun Jufo-luokitus) sekä yleisiä tietoja, kuten maksun summa. Lisäksi kirjasto merkitsee keskitetyn tuen seurannan kannalta oleelliset tiedot laskun kommentteihin ja reitittää laskun eteenpäin talouspalveluihin, jossa maksu tiliöidään kirjaston kommenttien perusteella. Talouspalvelut toimittavat kirjastoon raportin toteutuneista kirjoittajamaksuista pyydettäessä.

\section{Kohti tiiviimpää yhteistyötä}

Koska kirjoittajamaksuseuranta oli Itä-Suomen yliopistossa vielä alkuvaiheessa pilotin alkaessa, oli mielenkiintoista päästä tutustumaan muiden organisaatioiden seurantamalleihin. Myös seurantaansa aloittelevien organisaatioiden vaiheita oli hedelmällistä seurata. Itä-Suomen yliopiston tavoitteina pilotissa olivatkin verkostoituminen, tiedon jakaminen, hyvien käytänteiden kartoittaminen sekä oman seurannan evaluointi ja tehostaminen.

Miltei kaikki vuoden 2019 kirjoittajamaksutiedot siirrettiin OpenAPC:hen pilotin aikana. Muutkin tavoitteet pilotin osalta edistyivät. Kirjoittajamaksujen seurantataulukkoa kehitettiin vertaistuen avulla, kokemuksia ja toimintatapoja vaihdettiin organisaatioiden välillä ja näin ollen kuva kirjoittajamaksujen kirjosta ja seurannan tilanteesta maassamme tarkentui.

Pilotin myötä esiin nousi myös tarve tiiviimpään yhteistyöhön yliopiston julkaisuseurannan kanssa. Itä-Suomen yliopistossa kirjoittajamaksuseuranta ja julkaisuseuranta ovat toistaiseksi olleet eri palveluiden kontolla, mutta tulevaisuudessa yhteistyö tulee varmasti lisääntymään esimerkiksi kirjoittajamaksutietojen VIRTAan viemisen myötä. 
Julkaisumaksujen seuranta Laureaammattikorkeakoulussa

T utkimuslaitoksiin ja yliopistoihin verrattuna ammattikorkeakoulujen julkaisuprofiili painottuu vahvasti ammatilliseen julkaisemiseen, mutta tutkimus-, kehittämis- ja innovaatiotoiminnasta (TKI) ja hankkeista syntyy paljon myös tieteellisiä julkaisuja.

Ennen pilottiin osallistumista lähtötilanne Laurea-ammattikorkeakoulussa oli se, ettei tietoa artikkeleiden kirjoittajamaksuista oltu systemaattisesti kerätty ennen vuotta 2019, eikä Laurean julkaisupalveluilla ollut tarkkaa tietoa siitä, kuinka moni tieteellinen artikkeli oli julkaistu avoimesti esimerkiksi jonkin hankkeen budjetista.

\section{Maksukäytänteet muuttuvat}

Parin viime vuoden aikana Laurean julkaisupalvelut oli saanut kirjoittajilta tiedusteluita, voiko julkaisupalvelut maksaa kustantajalle APC-maksun. Maksumahdollisuus huomioitiin ensimmäisen kerran valmisteltaessa julkaisupalveluiden vuoden 2019 budjettia, silloin ja APC-maksuja varten varattiin kokeilumielessä pieni rahasto. Alkuvuodesta 2019 korkeakouluyksiköiden esimiehiä ja TKI-toimijoita tiedotettiin uudesta maksukäytänteestä ja julkaisupalvelut sai useita yhteydenottoja vuoden varrella.

Osallistuminen APC-pilottiin osui sopivaan saumaan täydentämään juuri käynnistynyttä APC-maksukäytäntöä ja -seurantaa. Oli mielenkiintoista pääs-

\section{APC-maksujen prosessikaavio LAU}

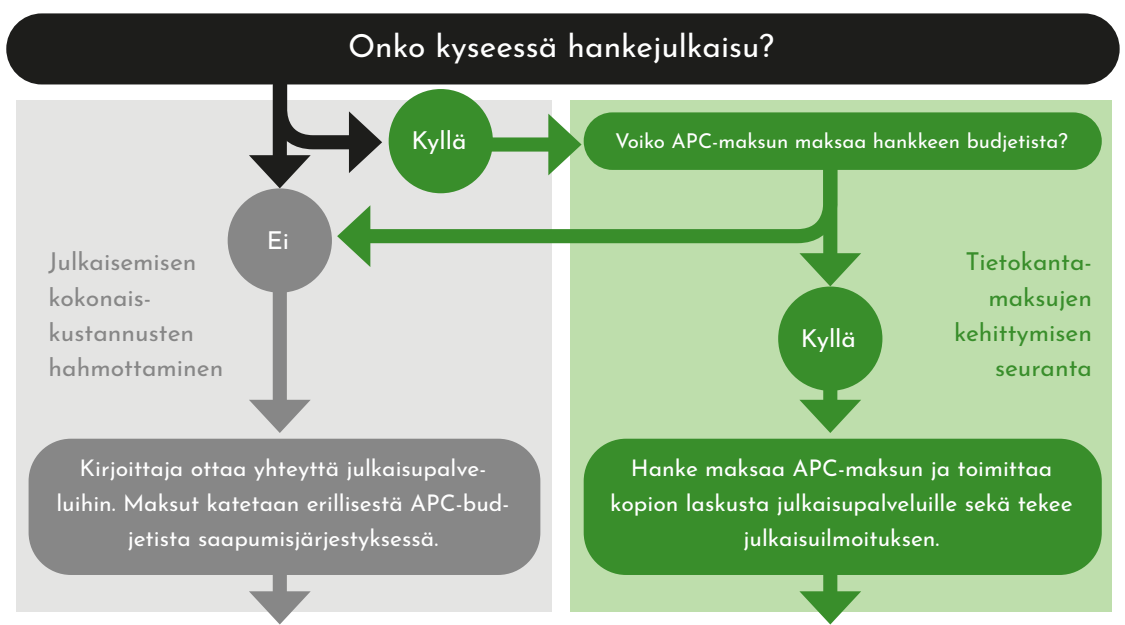

Julkaisupalvelut kerää APC-maksutiedot ja vie tiedot OpenAPC:hen vuosittain.

Laurean APC-maksujen prosessikaavio.

Kuva: Anna Laakkonen \& Maija Merimaa 
tä kuulemaan seurantaa jo pidempään tehneiden yliopistojen kokemuksia ja luomaan pohjaa yhteisille käytänteille.

Ennen APC-pilottia Laurean hanketoimijoilla ei ollut yhtenäistä käytäntöä siihen, miten julkaisukulut huomioidaan hankevalmisteluvaiheessa osana koko budjettia. Tähän haluttiin saada projektin myötä muutos. Asetimme Laureassa projektin tavoitteeksi julkaisumaksuja koskevan prosessin luomisen, ja tiedottamisen prosessiin kuuluville keskeisille TKI-toimijoille, hankehakemusvalmistelijoille sekä laskuntarkastajille.

\section{APC-maksujen prosessikaavio}

Kirjoittajamaksujen seurannan prosessikaavio lähtee oletuksesta, että tieteellinen artikkeli julkaistaan joko osana hanketta tai itsenäisenä artikkelina, osana ammattikorkeakoulussa tapahtuvaa TKI-toimintaa. APC-maksu pyritään saamaan osaksi hankebudjettia. Jos tämä ei ole mahdollista, kirjoittaja ottaa yhteyttä Laurean julkaisupalveluihin, joka maksaa APC-maksun ja edellyttää artikkelille cc-lisenssiä.

Prosessin taustalla pyritään hahmottamaan julkaisemisen kokonaiskustannukset ja vertaamaan niitä tietokantamaksujen kehittymiseen.

APC-projektin aikana vuoden 20I9 APC-maksutiedot toimitettiin Excel-taulukkona OpenapC-tietokantaan. Vuoden 2020 maksutietojen osalta toimitus automatisoituu, kun JUSTUs-julkaisutietojen tallennusjärjestelmään lisätään kenttä APC-maksutietoa varten.
Julkaisumaksujen seuranta Lukessa

utkimuslaitoksia edusti pilotissa Luonnonvarakeskus (Luke). Useimmissa tutkimuslaitoksissa APC-maksujen seuranta on vielä alkuvaiheessa. Seurannan tarve on kuitenkin tiedostettu ja kiinnostusta siihen on muissakin tutkimuslaitoksissa.

APC-maksuja ei pilotin alkaessa oltu Lukessa seurattu kokonaisuutena vielä lainkaan eikä mitään valmista prosessia seurannalle ollut. Pilotissa esitellyt yliopistojen seurantamallit vaikuttivat toimivilta, joten näitä esimerkkejä seuraten oli luonnollista lähteä myös Lukessa liikkeelle.

\section{Taloushallinnon ja kirjanpidon haasteet}

APC-maksujen selvittäminen aloitettiin keräämällä julkaisurekisteristä tiedot Luken avoimista julkaisuista. Näistä otettiin tarkempaan tarkasteluun ne, joissa vastuukirjoittajan organisaatio on Luke ja kirjoittajamaksun saattoi olettaa maksetun Lukessa. Artikkeleista kerättiin viitetiedot, DOI-tunniste sekä cc-lisenssi. Kustantajan sivuilta selvitettiin lisäksi lehden oA-malli ja APC-maksun suuruus.

Pilotin aikana jouduttiin toteamaan, että yliopistoissa toimivaksi havaittua yhteistyötä taloushallinnon kanssa on vaikea saada yhtä toimivaksi Lukessa. Luken taloushallintoa ja ostolaskujen käsittelyä hoitaa suurelta osin Valtion talous- ja henkilöstöhallinnon palvelukeskus Palkeet. Lisäksi Luken 
omat taloushallinnon asiantuntijat käsittelevät manuaalikiertoon päätyneet laskut. Luottokorttimaksujen osalta käsittelyn hoitaa kirjoittaja itse. Näin ison ja vaihtuvan laskuja käsittelevän joukon opastaminen tunnistamaan kirjoittajamaksut tuhansien laskujen joukosta osoittautui käytännössä mahdottomaksi.

Maksuja oli hankalaa tunnistaa myöskään kirjanpidosta. Lukessa on käytössä valtionhallinnon yhteinen kirjanpidon tilikartta, jossa julkaisumaksuille ei ole omaa tiliä eikä sitä ole mahdollista tilikarttaan lisätä. Luken APC-maksuja on kirjattu tilille Muut ulkopuoliset palvelut, johon kirjataan myös monenlaisia muita laskuja. Kirjoittajamaksujen seulominen tästä joukosta on aikaa vievää ja epävarmaa. Kävi myös ilmi, että osa julkaisumaksuista kirjataan muille tileille.

\section{Maksutietojen selvittäminen vaatii resursseja ja yhteistyötä}

Kirjoittajamaksujen selvittäminen vaatii runsaasti käsityötä ja yksityiskohtaista selvittämistä sekä monen henkilön työaikaa. Pilotin aikana todettiin, etteivät Luken resurssit riitä jokaisen yli 300 artikkelin selvittämiseen erikseen. Oletettavasti parhaiten maksun suuruudesta on selvillä kirjoittaja itse.

Myöhemmin tänä vuonna julkaisutiedonkeruuseen lisättävä kenttä APC-maksun ilmoittamista varten antaa tutkijalle mahdollisuuden ilmoittaa maksutieto julkaisuilmoitusta tehdessään. Tämä toivottavasti helpottaa maksuseurannan prosessia ja auttaa täydentämään tietoja.

Toistaiseksi Lukesta ei ole toimitettu tietoja OpenAPC-järjestelmään. Tiedonkeruun hankaluuksista huolimatta pilotin myötä vahvistui käsitys, että ainakin osa APC-maksutiedoista on saatavissa ja esimerkiksi konsortiosopimusten kautta avattujen artikkelien kustannukset ovat selvitettävissä. Täydellistä kattavuutta tuskin saavutetaan, mutta on parempi ilmoittaa edes vähän tietoja kuin ei mitään.

Osallistuminen pilottiin oli hyödyllistä, sillä sen myötä saatiin käsitys seurannan vaatimista monista vaiheista, työn vaatimuksista ja tarpeesta hioa prosessia. Lukessa kokeillaan tänä vuonna pientä yhteistä rahastoa APC-maksuille, joita ei ole mahdollista kohdentaa tutkimusprojekteille. Rahaston käyttökriteereihin saatiin hyviä ideoita ja malleja muilta pilottiin osallistuneilta.

\section{Lopuksi}

APC-maksujen seurannan kehittämisessä kannattaa yhä tiiviimmin selvittää maksutietojen kytkemistä osaksi julkaisutietojen ilmoittamista. On myös huomioitava, että organisaatiot ovat erilaisia monin tavoin: miten taloushallinto on järjestetty, kuinka paljon resursseja on käytettävissä ja kuinka paljon organisaatiossa julkaistaan vuosittain.

Tavoitteeksi tulee ottaa yksinkertainen, selkeä ja mahdollisimman automaattinen prosessi, jota eri toimijat 


\section{2}

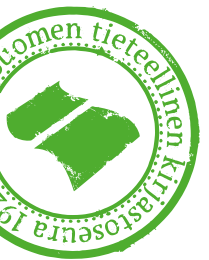

voivat yhtenäisin ehdoin ja käytännöin noudattaa organisaatiosta ja hallinnonalasta riippumatta. APC-maksuihin menevän euromäärän lisäksi on hyvä tarkastella, millaiset prosessit julkaisumaksujen hallinnoinnilla organisaatiossa on ja mitä muita julkaisemiseen liittyviä maksuja maksetaan.

On hyvä, että korkeakoulut ja tutkimuslaitokset ovat viime vuosina heränneet tarkastelemaan avoimeen julkaisemiseen liittyviä kustannuksia. Näin saamme tarkempaa tietoa tieteellisen julkaisemisen kokonaiskuvasta ja -summasta eli siitä, kuinka paljon, mistä kaikesta ja mille tahoille suomalaiset tutkimusorganisaatiot julkaisemisesta maksavat. Tämä on tärkeää tietoa tutki- musta tekevien organisaatioiden ja julkisella rahalla tuotetun tieteen kannalta ja oleellista myös tutkimusrahoittajien näkökulmasta.

Kun suomalaisten tutkimusta tekevien organisaatioiden maksamien APC-maksujen kokonaiskustannukset alkavat hahmottua, tulisikin käydä keskustelua siitä, mikä on se tapa ja mitkä ovat ne kustannusmallit, joilla avointa julkaisemista halutaan jatkossa tukea. Onko APC-maksuihin käytetty summa kohdistettu järkevimmällä tavalla eli niihin kanaviin ja niille tahoille, joista saamme eniten hyötyä tutkimukselle, avoimelle tieteelle, organisaatioille ja yksittäisille tutkijoille?

\section{Lähde:}

Rantasaari, Jukka, Marjo Kuusela \& Kalle Tittinen 20i 8: Avoimen julkaisemisen kirjoittajamaksukäytännöt Suomen yliopistoissa. Blogikirjoitus 5.4.20I 8. Suomen yliopistokirjastojen verkoston blogi. http://yliopistokirjastot.fi/avoimen-julkaisemisen-kirjoittajamaksukaytannot-suomen-yliopistoissa/ (luettu 4.4.2020)

\section{Tietoa kirjoittajista}

Arto Ikonen

Avoimen tiedon keskus

(Jyväskylän yliopisto)

arto.ikonen@jyu.fi

AnNa LaAKKonen

Laurea-ammattikorkeakoulu

anna.laakkonen@laurea.fi
JuHO Jussila

Itä-Suomen yliopiston kirjasto

juho.jussila@uef.fi

Anna-KaArina Linna

Turun yliopiston kirjasto

anna-kaarina.linna@utu.fi

Sirpa SuonpäÄ

Luonnonvarakeskus

sirpa.suonpaa@luke.fi 